\title{
3.0T MR装置による肝蔵のT2*map測定シーケンスの検討
}

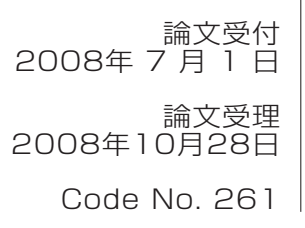

\section{緒 言}

慢性肝疾患の患者には, 肝臓の局所的あるいはび まん性に鉄沈着を伴う場合がある．肝臓の鉄代謝の 異常は肝機能を反映し，へモクロマトーシスやへモジ デローシスのような疾患が挙げられる。この場合, 血 液・血清学的な検査を行うことが代表的であるが, MR検査によるイメージングでも評価が可能である1). 特に, T2*值は鉄沈着による局所磁場の不均一の影 響を受け，その測定は肝機能を評価するために有用 との報告がある2). さらに3.0Tに代表される高磁場 MR装置では, 磁化率の影響を強く受けるために, 鋭
敏にT2*值の変化を捉えることができると考えられて いる3,4).また， $\mathrm{T} 2 *$ 值を強調する $\mathrm{T} 2 *$ 強調画像のみな らずピクセルごとのT2*值を画像上に表現したT $2 *$ map は視覚的にT2*值の分布を知ることができる ${ }^{4)}$.

T2*mapを得るためのシーケンスは主にfield echo法 を利用し，エコー時間 $(\mathrm{TE})$ を変化させることで $\mathrm{T} 2 *$ 緩 和曲線を求め, その時定数である $\mathrm{T} 2 *$ 值を得る方法が 一般的である(multi-echo fast field echo法 以下, mFFE法とする). また, echo planar imagingシーケン スについても, ブリップ傾斜磁場を除き, マルチエ コーを得てT2*值を求めることが可能である4) $($ multi-

\section{Investigation of $\mathrm{T} 2^{*}$ map Measurement Sequence in the Liver at 3.0T MR}

\author{
Masanori Komi, Kousuke Morita, and Masahiro Hashida \\ Department of Radiology, Kumamoto University Hospital Division of Medical Technology \\ Received July 1,2008; Revision accepted Oct. 28,2008; Code No. 261
}

\section{Summary}

T2* value measurement of the liver parenchyma with a 3.0T MR scanner may be useful for evaluating focal liver function. Currently, there are 2 sequences for measurement of $\mathrm{T} 2 *$ value of the liver: multi-echo fast field echo (mFFE), and multi-echo planar imaging (EPI). We can correct inhomogeneity of the local magnetic field with the EPI sequence; however, the spatial resolution is poor. On the other hand, mFFE has a relatively high spatial resolution but cannot correct inhomogeneity of the local magnetic field. We investigated the two measurement methods of a T2* map that measured the T2* images obtained with mFFE and EPI sequences by using a 3.0T MR scanner in the phantom and patient studies. In the phantom studies, T2* values measured on images with the mFFE sequence were affected by inhomogeneity of the local magnetic field, but T2* values measured on images with the EPI sequence were showed no difference by corrected inhomogeneity of local magnetic field. However, in the clinical study, we found good agreement in $\mathrm{T} 2 *$ values of the liver measured on images with $\mathrm{mFFE}$ and EPI sequences. Therefore, the mFFE sequence can be an alternative to the EPI sequence in the clinical setting. It is occasionally difficult to identify normal or pathological structures on images obtained with the EPI sequence because of its low spatial resolution. The spatial resolution of images obtained with the mFFE sequence is much better than that with the EPI sequence. Based on these discussions, we believe that the mFFE sequence may be appropriate for the measurement of $\mathrm{T} 2 *$ values in the liver in the clinical setting.

Key words: T2* map, iron deposit, 3.0T MR, multi-echo fast-field echo (mFFE), multi-echo planar imaging (EPI)

別刷資料請求先： $=860-8556$ 熊本市本荘1-1-1

熊本大学医学部附属病院 医療技術部診療放射線技術部門 小味昌憲 宛 
echo planar imaging法 以下, EPI法とする). 一般的 に, T2*值の測定では局所磁場の不均一による影響が 大きく，その值を正確に測定することは困難である. 特に, EPI法はmFFE法よりも局所磁場の不均一によ る影響が大きいと予測されるので, その影響を補正 することが必要であると考えられる。当院の3.0T MR 装置では, 局所磁場の不均一補正がないmFFE法と 局所磁場の不均一補正のあるEPI法が可能であるが, 両者における $2 *$ mapの比較検討は行われていない.

本研究の目的は, 3.0T MR装置において局所磁場 の不均一補正がないmFFE法と局所磁場の不均一補 正があるEPI法を使用したT2*mapの測定精度をファ ントムで比較検討し, さらに臨床においてどちらの方 法が有用かを検討することである.

\section{1. 方 法}

\section{1-1 装置と解析ソフトウェア}

使用した装置は，フィリップス社製3.0T MR装置 Achieva Release2.1であり, T2*mapの解析ソフトウェ アとしてフィリップス社製PRIDEを用いた。

当院で, $\mathrm{T} 2 *$ 值の測定に使用できる 2 種類のシーケ ンスはmFFE法とEPI法である. 両者の特徴的な違い は, mFFE法は空間分解能を高く撮像することができ るが局所磁場の不均一補正ができない.一一方, EPI法 は局所磁場の不均一補正が可能だが空間分解能が低 い. 空間分解能についてはMR装置と解析ソフトの都 合上，両シーケンスで同一にすることができず，通常 撮像している条件のパラメータに従った。

\section{1-2 T2*值の測定方法}

\section{1-2-1 mFFE法}

シーケンスはマルチエコータイプのfield echo法で あり, RF励起パルスの後にリードアウト方向の傾斜 磁場を高速に反転させることでエコーを収集する.

撮像パラメータは次のとおりである。

$\mathrm{TR}=377 \mathrm{msec}, \mathrm{TE}=2.3 \sim 46 \mathrm{msec}$ (echo step : $2.3 \mathrm{msec}$ ), number of echo=20, FOV $=400 \mathrm{~mm}$,

$208 \times 144$ matrix, thickness $=7.0 \mathrm{~mm}$, scan time $57 \mathrm{sec}$ そして, T2*值は次の関係式から求めることができ る.

$$
\begin{aligned}
\mathrm{S}_{\triangle} \mathrm{B}_{0}(\mathrm{TE}) & =\mathrm{S}_{0} \cdot \exp (-\mathrm{TE} / \mathrm{T} 2 *) \\
\mathrm{S}: \text { 信号強度 } & \\
\mathrm{S}_{\Delta} \mathrm{B}_{0}(\mathrm{TE}) & \text { 任意の } \mathrm{TE} \text { において磁場変動 }{ }_{\Delta} \mathrm{B}_{0} に \\
& \text { おける信号強度 }
\end{aligned}
$$

$\mathrm{S}_{0}$ : 初期信号強度

\section{1-2-2 EPI法}

EPIを基本とし，シングルショットEPIのブリップ傾
斜磁場を省き, 位相エンコードを繰り返してk-space を充填するように変更されたシーケンスを用いてマル チエコーを得る.

撮像パラメータは次のとおりである.

$\mathrm{TR}=348 \mathrm{msec}, \mathrm{TE}($ effective TE$)=25 \mathrm{msec}, \mathrm{EPI}$ factor (number of echo) $=29, F O V=400 \mathrm{~mm}$, $128 \times 96$ matrix, thickness $=7.0 \mathrm{~mm}$, scan time $9 \mathrm{sec}$ 次の関係式により $2 *$ 值を求めることができる.

$\mathrm{S}_{\Delta} \mathrm{B}_{0}(\mathrm{TE})=\mathrm{S}_{0} \cdot \exp (-\mathrm{TE} / \mathrm{T} 2 *) \cdot\left|\left\{\sin \left(v_{\Delta} \mathrm{B}_{0} / 2 \mathrm{TE}\right)\right\} /\left(v_{\Delta} \mathrm{B}_{0} / 2 \mathrm{TE}\right)\right|$ $\mathrm{S}$ : 信号強度

$\mathrm{S}_{\Delta} \mathrm{B}_{0}(\mathrm{TE})$ : 任意のTEにおいて磁場変動 ${ }_{\Delta} \mathrm{B}_{0}$ に おける信号強度

$\mathrm{S}_{0}$ : 初期信号強度

$v ：$ Z軸方向の位相誤差

この式の $\sin$ 以降の項により, 局所磁場の不均一補 正が行われる.

\section{1-3 ファントムを用いたT2 $*$ 值測定精度の検討}

PVAゲルを用いたファントム90-401型(日興ファイ ンズ工業社製)を使用した。その中の 3 本の測定試料 封入部に, おのおの次に示す試料を作成し挿入し た.ファントムの概観をFig. 1に示す.

試料 $1 \cdots 1.0 \mu \mathrm{mol} / \mathrm{mL} の$ super paramagnetic iron oxide (以下, SPIO)造影剤を封入したもの(T1值：700 msec,

T2值 : 40msec)

試料 $2 \cdots 0.5 \mu \mathrm{mol} / \mathrm{mL}$ のSPIO造影剂を封入したもの (T1值：250msec, T2值 : $60 \mathrm{msec}$ )

試料 $3 \cdots$ 生理食塩水を封入したもの

また，3.0Tにおける肝蔵の一般的な $\mathrm{T} 1$ 值と $\mathrm{T} 2$ 值 は，およそ640msecと45msecである。

次に, Fig. 2に示すように, このファントムを二つ の状態において, mFFE法とEPI法でおのおの 5 回撮 像した. 二つの設置状態とは, 通常の設定(以下, situation_1) と, 意戝的に局所磁場を変化させるため に水ボトルをファントムと一緒に撮像した場合(以 下, situation_2)である.

mFFE法とEPI法で得られた画像を解析ソフト PRIDEにて計算し， T2*mapを得た。試料 1 と試料 2 の部分に, ROI (関心領域：サイズは55ピクセル)を設 定し，その部分のT2*值を一人の測定者が測定した。

測定したROIの位置をFig. 3に示す.

mFFE法とEPI法において測定したT2*值を, situation_1 とsituation_2の場合について, 対応ある 2 群 のt検定で有意差を検討した.

\section{1-4 臨床例によるT2*mapの検討}

当院倫理委員会の承認を受け, 本研究の目的を説 明し, 同意を得た患者20名：男性17名・女性 3 名 (44 


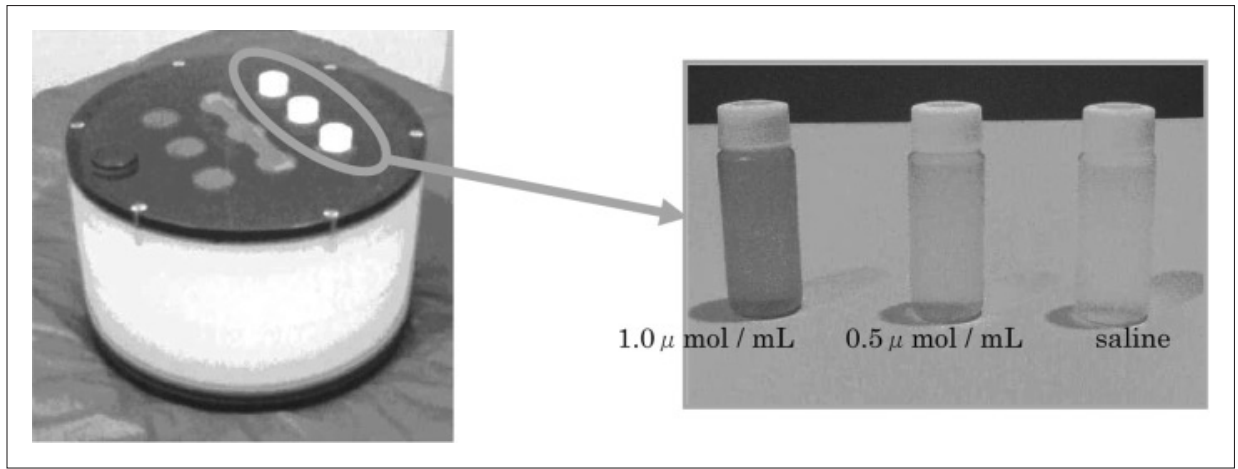

Fig. 1 Phantom.

(a) Phantom type 90-401 (Nikko Fines Industries, Tokyo, Japan). We used an MRI phantom made of polyvinyl alcohol (PVA) gel for the phantom study.

(b) Syringes filled with diluted SPIO and saline. Three syringes filled with diluted super-paramagnetic iron oxide (SPIO) solution with concentrations of 1.0 and $0.5 \mu \mathrm{mol} / \mathrm{mL}$ and saline were inserted into the phantom.
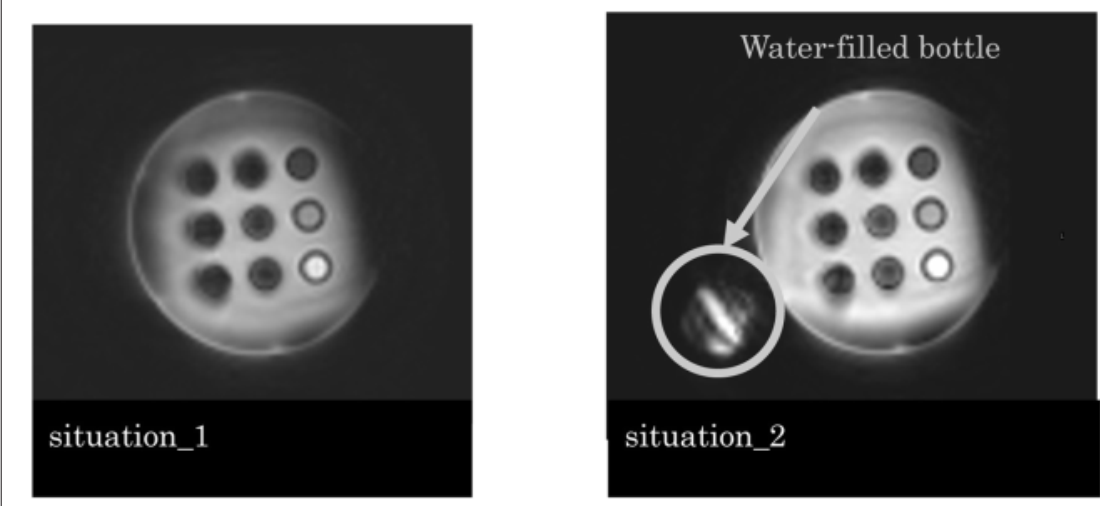

Fig. 2 Objects in the phantom studies.

First, the phantom was scanned solely with the mFFE and EPI sequences (situation_1). We then placed a bottle filled with $500 \mathrm{~mL}$ of water just adjacent to the right side of the phantom.

The water-filled bottle induced inhomogeneity of the magnetic field. Then the phantom and water-filled bottle were scanned with the mFFE and EPI sequences again (situation_2).

～85歳 平均年齢：66.4歳)を対象患者とした。疾患 の内訳は, 肝細胞癌 12 名・大腸癌の肝臓転移 5 名 肝囊胞 1 名・正常肝 2 名である.

mFFE法とEPI法で肝臓のAxial画像の撮像を行っ た。撮像は呼吸停止下で行い, 解析ソフトPRIDEで $\mathrm{T} 2 *$ mapを作成した。両者の $\mathrm{T} 2 * \mathrm{map}$ 上で一人の測定 者が肝左葉の外側区域と内側区域と肝右葉の後区域 にROI (関心領域：サイズは110ピクセル)を設定し て，その部分の 2 2*值を測定し，その 3 力所の平均の T2*值を求めた. Fig. 4に設定したROIを示す。そし て, mFFE法とEPI法によるT2*值の相関を統計的手 法としてスピアマンの相関係数で判断した.

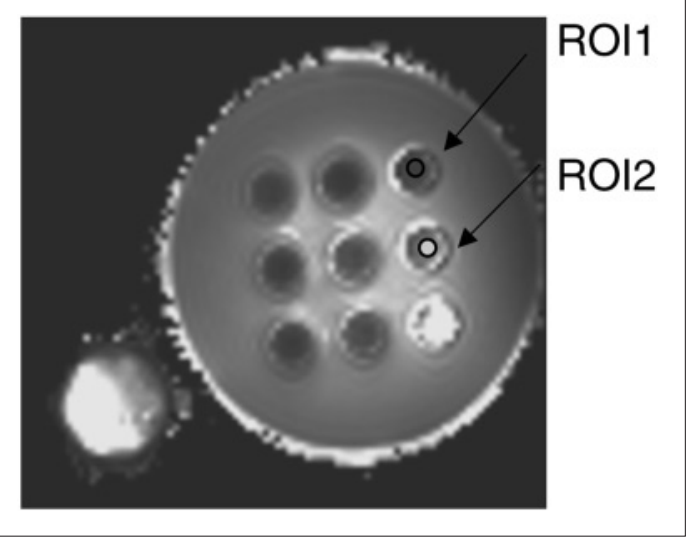

Fig. 3 Measurement T2* values of the SPIO solution for the calculated T2* images were obtained with mFFE and EPI (ROI 1 and ROI 2). 


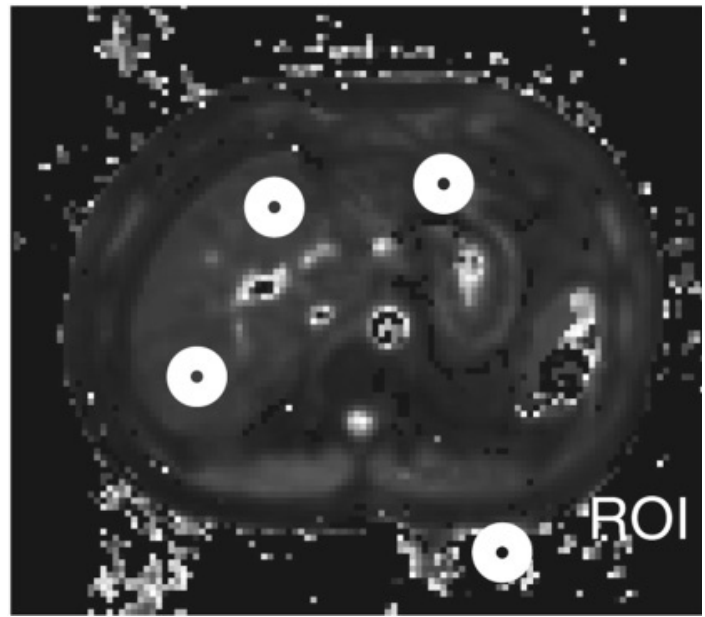

Fig. 4 Clinical case.

Measurement $\mathrm{T}^{*}$ values of the liver on the calculated T2* images obtained with mFFE and EPI.

White circle shows ROI (Region of Interest).

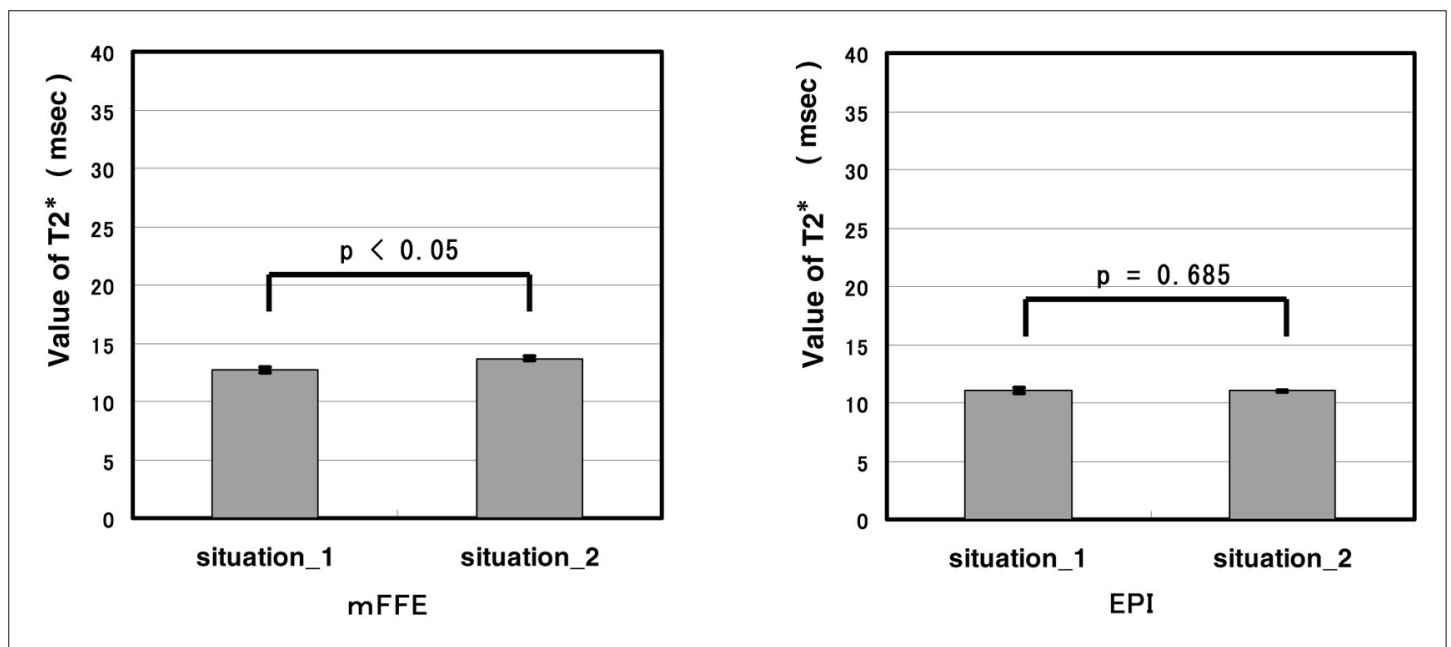

Fig. 5 Results of the syringe filled with $1.0 \mu \mathrm{mol} / \mathrm{mL}$ SPIO (ROI 1) in each scan.

Intensity of ROI 1 in situation_1 was statistically significantly lower than that in situation_2 on calculated T2* images obtained with mFFE, while there was no statistically significant difference in the intensity of ROI 1 between scan situation_1 and situation_2 on calculated T2* images obtained with EPI.

\section{2. 結 果}

2-1 ファントムを用いたT2*值測定精度の検討結果 試料 1 における $\mathrm{mFFE}$ 法とEPI法から求めたT2*值 の比較をFig. 5に示す。試料 1 は $1.0 \mu \mathrm{mol} / \mathrm{mL}$ のSPIO 造影剤であるが, mFFE法の場合, situation_1とsituation_2において, 対応ある 2 群のt検定を行うと, $\mathrm{p}<0.05$ となり，危険率 $5 \%$ で有意差があった。 EPI法 の場合は, situation_1 とsituation_2 の状態で, $\mathrm{p}=0.685$ となり有意差はなかった.

試料 2 における $\mathrm{mFFE}$ 法とEPI法から求めたT $2 *$ 值 の比較をFig. 6に示す. 試料 2 は $0.5 \mu \mathrm{mol} / \mathrm{mL}$ のSPIO 造影剤であるが, mFFE法の場合, situation_1 とsituation_2 の状態で, 対応ある 2 群のt検定を行うと, $\mathrm{p}<0.05$ となり，危険率 $5 \%$ で有意差があった，EPI法
の場合は, situation_1とsituation_2の状態で, $\mathrm{p}=0.225$ となり有意差はなかった。

\section{2-2 臨床例によるT2*値の検討結果}

臨床画像のmFFE法とEPI法によるT2*值のスピア マン相関係数による結果をFig. 7に示す。相関係数は 0.86 で両者のT2*值に相関がみられた.

\section{3. 考 察}

ファントムを用いた $\mathrm{T} 2 *$ 值測定精度の検討に関し て, mFFE法ではファントムの設置状況により局所磁 場に不均一が起こり, その補正がなされないために T2*值に差がみられた(Fig. 5, 6). EPI法では, 局所 磁場の不均一補正が行われたのでファントムの設置 

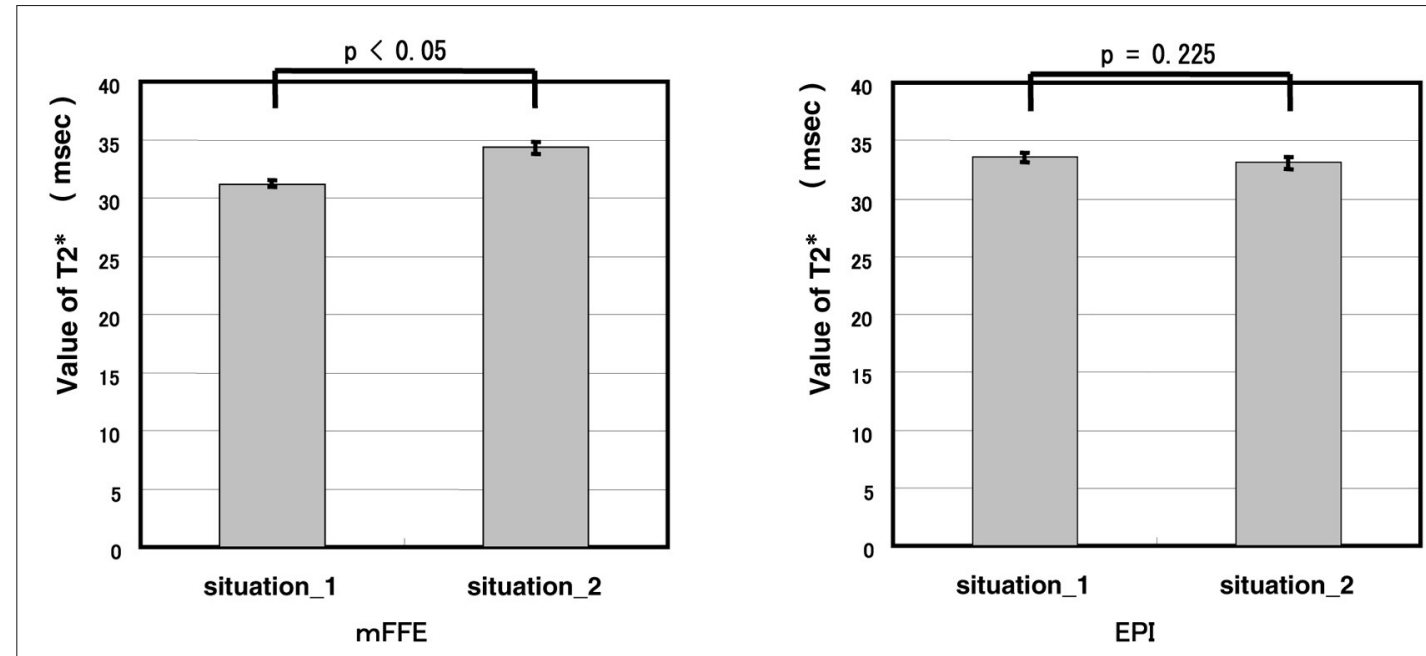

Fig. 6 Results of the syringe filled with $0.5 \mu \mathrm{mol} / \mathrm{mL}$ SPIO (ROI 2) in each scan. Intensity of ROI 2 in situation_1 was statistically significantly lower than that in situation_2 on calculated T2* images obtained with mFFE, while there was no statistically significant difference in intensity of ROI 2 between situations 1 and 2 on calculated T2* images obtained with EPI.

状況による差はみられなかった(Fig. 5，6)。この点に ついて, シーケンスを比較した場合，局所磁場の不 均一の影響を受けやすいのはEPI法であり ${ }^{4)}$, 特に本 研究で用いたEPI法のシーケンスではブリップ傾斜磁 場を意図的に除いているため，その時間分だけ位相 分散が大きくなると推測される。したがって, EPI法 はmFFE法よりも局所磁場の不均一の影響を強く受け るため，その補正が必要になると考える。したがっ て, mFFE法とEPI法のおのおのについて局所磁場の 不均一を把握することが必要であるが，ファントム実 験での局所磁場の不均一の程度は，局所磁場の変動 を示す ${ }_{\triangle} \mathrm{B}_{0}$ を得ることで推定できる。 ${ }_{\Delta} \mathrm{B}_{0}$ は静磁場の 中心磁場強度からずれた磁場強度, 言い換えると変 動した局所の磁場強度をppm（parts per million）で表 したものであり, 本研究で用いた解析ソフトPRIDE で，この ${ }_{\Delta} \mathrm{B}_{0}$ をmapとして得ることができる，そこで， ファントムの試料 1 におけるsituation_1とsituation_2 の ${ }_{\triangle} \mathrm{B}_{0}$ を求めると, $\mathrm{mFFE}$ 法でおのおの $12.5 \pm 1.8 \mathrm{ppm}$ であり, EPI法でおのおの16.9 $1.3 \mathrm{ppm}$,

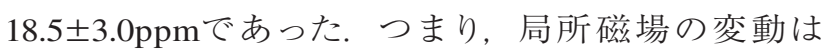
situation_1とsituation_2の両方においてmFFE法よりも EPI法の方が大きく, 局所磁場の不均一補正の効果は EPI法でより顕著になることが考えられる。もちろん mFFE法に扔いても局所磁場の不均一補正により $\mathrm{T} 2 *$ mapの測定精度が増すことは予測できるが, 本研 究においては解析ソフトの制限によりその確認を行う ことができなかった。

臨床例の検討においては, mFFE法とEPI法による T2*值はよく相関しておう (Fig. 7), 撮像シーケンスと

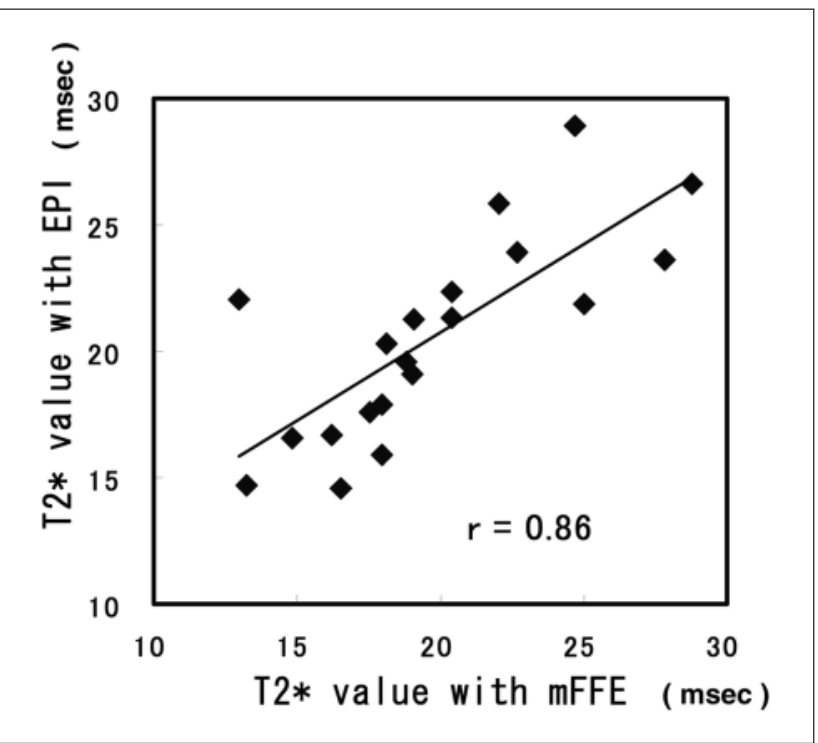

Fig. 7 Correlation of $\mathrm{T}^{*}$ values of the hepatic parenchyma between mFFE and EPI.

The correlation coefficient of T2* value between mFFE and EPI was 0.86 .

局所磁場の不均一補正の有無による違いを認めるに は至らなかった。これはファントムでの検討で設置状 況を変えた水のボトルの影響を, 臨床例の状況では 再現できなかったことが原因と思われる。臨床例にお いても, ファントムでの検討のように, 局所的な磁場 均一性を変化させることを再現できればMFFE法と EPI法で違いが表れる可能性がある.

次に, $\mathrm{T} 2 * \mathrm{map}$ 空間分解能に関して考察する. 肝 の限局的な腫瘤性病変である肝細胞癌と鉄沈着再生 

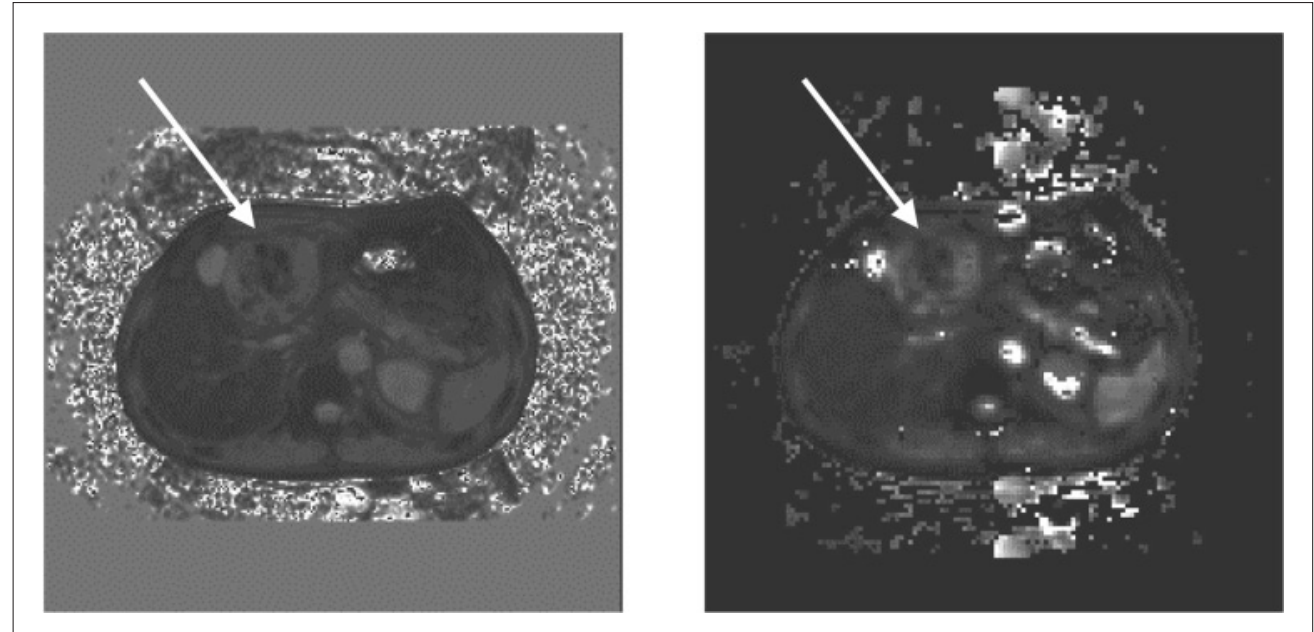

Fig. 8 Clinical case.

(a) mFFE

(b) EPI

Hepatocellular carcinoma (HCC) $(\rightarrow)$ with T2* map acquired with mFFE and EPI. T2* map obtained with MFFE (a) and T2* map obtained with EPI (b). T2* map obtained with mFFE is a higher resolution image than that of EPI.

結節の鑑別においては, 磁化率の効果が診断に役立 つとされており ${ }^{5,6)}$, その限局的な腫瘤性病変の大き さに関して, 慢性肝疾患の症例に小結節が検出され た場合, それが肝細胞癌である確率は, 大きさが 10mm以下で27.4\%, 11〜 15mmで51.9\%であり, $10 \mathrm{~mm}$ 以下では境界病変が多く含まれると報告されて いる7). 通常の再生結節の大きさが 2 $5 \mathrm{~mm}$ であるこ とを考えると $5 \mathrm{~mm}$ 以下の病変では肝細胞癌との鑑別 も困難であることが考える7). したがって， T2*mapで 限局的な肝腫瘤性病変を診断するには空間分解能が高 いことが必要となる. 今回, 空間分解能を表すピクセ ルサイズは撮像条件から, mFFE法で $1.92 \mathrm{~mm} \times 2.77 \mathrm{~mm}$ (周波数方向 $\times$ 位相方向), EPI法で $3.12 \mathrm{~mm} \times 4.16 \mathrm{~mm}$ (周波数方向 $\times$ 位相方向)であり, mFFE法は空間分解 能が高い点で解剖学的構造を認識しやすいと思われ る. 実際の症例をFig. 8に示すが, mFFE法とEPI法の 空間分解能の違いは腫瘍サイズが大きい場合にも内 部構造のT2*mapに影響を及ほしていることが確認で きる。

今回の臨床例での評価は, 肝臓の肝門部付近で右 葉・左葉あるいは内側区・外側区が確認しやすいス ライス画像で行っている. 3.0Tの磁化率の影響が大 きいと思われる横隔膜ドーム下や心臓と接する左葉 の評価は行っていないが, mFFE法よりもEPI法が, 横隔膜ドーム下や心臓と接するスライス画像に局所 磁場の変動を表す ${ }_{\Delta} \mathrm{B}_{0}$ が大きくなることが予測される.

以上の点から, T2*map測定においてEPI法はmFFE
法よりも磁化率の影響を受けやすく, 局所磁場の不 均一補正が必要であるが, mFFE法の空間分解能は EPI法よりも高く, Fig. 7で明らかなようにmFFE法と EPI法に相関があれば, mFFE法でも臨床例で使用で きると考えられる。つまり, 肝蔵のT $2 *$ map測定に用 いるシーケンスは, 空間分解能を考慮してmFFE法が 適していると考える. 今後, mFFE法で局所磁場の不 均一補正が可能になればさらにT $2 *$ 值の測定精度が 増すと思われる。

\section{4. 結 語}

3.0T MR装置における肝臓のT $2 * \operatorname{map} の$ 測定に関し て, 局所磁場の不均一補正のないmFFE法と局所磁 場の不均一補正のあるEPI法を比較検討した。ファン トム実験では, EPI法がmFFE法よりも局所磁場の不 均一補正が行われたので, ファントムの設置状況に よるT2*值に差がみられなかった。しかし, 臨床例で は, mFFE法とEPI法にT2*值の相関がみられたので, 現状では空間分解能を考慮して, 臨床上, EPI法より もmFFE法が有用であることが示唆された。

\section{謝辞}

本研究に際しまして, 助言ならびに協力をいただき ました株式会社フィリップスエレクトロニクスジャパ ン 奥秋知幸氏, 斎木秀太郎氏に深く感謝いたしま す. 


\section{参考文献}

1) Ebara M, Watanabe S, Kita K, et al. MR imaging of small Hepatocellular Carcinoma: Effect of intratumoral Copper content on signal intensity. Radiology 1991; 180(3): 617-621.

2) Gandon Y, Guyader D, Heautot JF, et al. Hemochromatosis: diagnosis and quantification of liver iron with gradientecho MR imaging. Radiology 1994; 193 (2) : 533-538.

3) Mansfield P. Spatial mapping of the chemical shift in NMR. Magn Reson Med 1984; 1(3) : 370-386.

4) Dahnke H, Schaeffter T. Limits of detection of SPIO at 3.0
T using T2 relaxometry. Magn Reson Med 2005; 53(5): 1202-1206.

5) 角谷眞澄, 藤永康成. 肝疾患の画像診断: 最近の進歩と 将来展望. 4. MRI：撮像法と画像所見. 肝臓 2006；47 (4) : 195-202.

6）兼松雅之. 各種画像診断における最近の進歩：肝のMRI 診断－CADの応用を含めて一。医用画像情報会誌 2005 ； 22(3) : 194-197.

7) 諸井 中, 遠田栄一, 嶋村賢司. 肝疾患の超音波検査一 限局性肝疾患一。超音波検査技術 1994；19(1)：43-53.

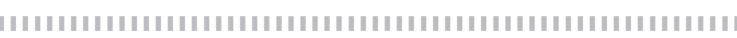

Fig. 1 使用したファントムの概観

(a) PVAゲルファントム 90-401型

(b) 超常磁性酸化鉄 $(\mathrm{SPIO})$ の希釈液ファントム $(1.0 \mu \mathrm{mol} / \mathrm{mL}, 0.5 \mu \mathrm{mol} / \mathrm{mL})$ と生理食塩水を満たしたファントム

Fig. 2 ファントムの設置状況が異なるsituation_1 とsituation_2 の説明

situation_1 は通常のファントム設置を示し, situation_2 は局所磁場の不均一を得るために500mLの水を満たしたボトルを ファントムと同時に設置した.

Fig. 3 ファントムにおいいて, mFFE法とEPI法でT2*值を計算させた場合の, 関心領域(ROI 1とROI 2)の設定を示す.

Fig. 4 臨床例において, mFFE法とEPI法でT2*mapを計算させた場合の, 肝臓の関心領域(ROI)の設定 肝左葉の外側区域と内側区域，および右葉後区に設定した.

Fig. $51.0 \mu \mathrm{mol} / \mathrm{mL}$ のPIO希釈液のT2*值の結果を示す. mFFE法ではsituation_1 とsituation_2 の統計的有意差があった $(\mathrm{p}<0.05)$. EPI法ではsituation_1 とsituation_2 の統計的有 意差がなかった $(\mathrm{p}=0.685)$.

Fig. $60.5 \mu \mathrm{mol} / \mathrm{mL}$ のPIO希釈液のT2*值の結果を示す.

mFFE法ではsituation_1 とsituation_2の統計的有意差があったp<0.05). EPI法ではsituation_1 とsituation_2の統計的有 意差がなかった $(\mathrm{p}=0.225)$.

Fig. 7 臨床例におけるmFFE法とEPI法による肝実質のT2*值の相関を示す.

相関係数は 0.86 を示し, 強い相関が認められる.

Fig. 8 mFFE法とEPI法による肝細胞癌のT2*mapを示す.

(a)はmFFE法によるT2*map, (b)はEPI法によるT2*mapである. mFFE法によるT2*mapはEPI法によるものよりも空間分 解能に優れる。 